\title{
A Brief Talk of the Disinfection Process for Reclaimed Water
}

\author{
Zhiqiang Feng ${ }^{1}$, Rongrong Xue ${ }^{2 *}$, Liyan $\mathrm{Ge}^{1}$ \\ ${ }^{1}$ Tianjin Research Institute for Water Transport Engineering, Key Laboratory of Environmental Protection in Water transport \\ Engineering, Ministry of Transport, 300456, China \\ 2 Tianjin DongFang TaiRui Technology Co.,Ltd,300192, China
}

\begin{abstract}
In recent years, with the reclaimed water being more and more widely used, people begin to pay more and more attention to the security of it. Because the reclaimed water comes from the sewage, which has been deeply treated, its quality is quite complex and it may contain many bacteria, viruses and poisonous that are harm to people. When it's reused, it is inevitable that the reclaimed water may come into contact with people's body, which has exposure risk. In order to reduce the risk of exposure, ensure the security of the quality of the reclaimed water, the disinfection becomes the most critical factors in dealing with the reclaimed water in the process. In the paper, the current disinfection techniques were discussed and compared in the aspects of technical features, the effects of disinfection and economy. And a brief summary of the new disinfection technology that was widely studied was made.
\end{abstract}

\section{Preface}

With the rapid development of the world economy, the shortage of water resources has attracted people's attention. Reuse of reclaimed water has become an effective way to solve this problem. In the process of reuse of reclaimed water, the safety of reclaimed water quality is the most noteworthy factor, disinfection is the last link in the reclaimed water treatment process, which plays a key role in ensuring the safety of reclaimed water quality.

Reclaimed water disinfection methods can be basically divided into three categories: 1. Chemical disinfection, Including chlorine, chlorine dioxide and ozone disinfection; 2. Physical disinfection, including ultraviolet disinfection, micro-electrolysis disinfection, and ultrasonic disinfection;3. Combined disinfection methods, such as UV-chlorine disinfection ${ }^{[1]}$.

\section{Chemical disinfection}

\subsection{Chlorine disinfection}

Chlorine $\left(\mathrm{Cl}_{2}\right)$ soluble in water (When $20^{\circ} \mathrm{C}$ and $98 \mathrm{kPa}$, Solubility $7160 \mathrm{mg} / \mathrm{L}$ ) .When chlorine dissolves in clean water,The following two reactions occur almost instantaneously:

$$
\mathrm{Cl}_{2}+\mathrm{H}_{2} \mathrm{O} \rightleftarrows \mathrm{HClO}+\mathrm{HCl}
$$

The reaction rate of this reaction is: $\mathrm{K}_{25^{\circ} \mathrm{c}}=6.5 \times 10^{-14}$ $\left(\mathrm{cm}^{3} / \text { molecules }\right)^{[2]}$,

$$
\mathrm{HClO} \leftleftarrows 二=\Longrightarrow \mathrm{ClO}^{-}+\mathrm{H}^{+}
$$

The equilibrium constant of the dissociation reaction is: $\mathrm{K}_{\mathrm{i}}=\frac{\left[O \mathrm{OCl}-\mid\left[\mathrm{H}^{+}\right]\right.}{[\mathrm{HOCl} \mid}$,See Table1 for the dissociation constant of hypochlorous acid at different temperatures.

Table 1. Hypochlorous acid dissociation equilibrium constant

\begin{tabular}{|c|c|c|c|c|c|c|}
\hline $\begin{array}{c}\text { Temperature } \\
\left({ }^{\circ} \mathrm{C}\right)\end{array}$ & 0 & 5 & 10 & 15 & 20 & 25 \\
\hline $\mathrm{K}_{\mathrm{i}} \times 10^{-8}$ & 2.0 & 2.3 & 2.6 & 3.0 & 3.3 & 3.7 \\
\hline
\end{tabular}

Hypochlorous acid plays a major role in chlorine disinfection $\mathrm{HOCl} . \mathrm{HOCl}$ is a small neutral molecule, It can spread to the surface of negatively charged bacteria, And penetrate into the inside of the bacteria through the cell wall of the bacteria. When the $\mathrm{HOCl}$ molecule reaches the inside of the bacteria,it can oxidize and destroy the enzyme system of bacteria and cause bacteria to $\mathrm{die}^{[3]}$. Although hypochlorite $\left(\mathrm{OCl}^{-}\right)$also has the ability to kill bacteria, but because it is negatively charged, it is difficult to access the same negatively charged bacteria surface, and its sterilization ability is much worse than that of $\mathrm{HOCl}^{[4]}$.

According to Table 1, the percentage of $\mathrm{HOCl}$ in water at different $\mathrm{pH}$ values and temperatures can be calculated and figure 1 can be drawn.

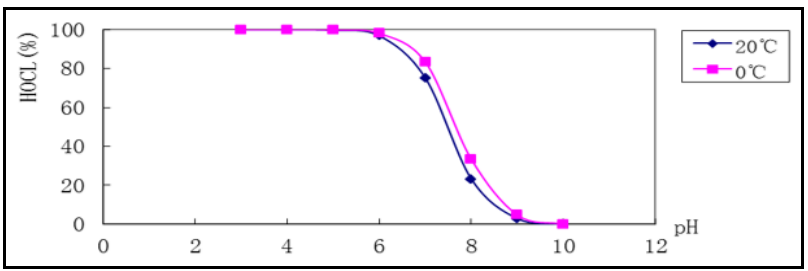

Figure 1. The ratio of HOCL and OCL- in the water at different $\mathrm{pH}$ values and water 
It is not difficult to see from Figure 1, At a certain temperature, when the $\mathrm{pH}$ value is higher, $\mathrm{ClO}$ - is more, when $\mathrm{pH}>9.0$, OCl- approaches $100 \%$; When the $\mathrm{pH}$ value is low, there is more $\mathrm{HOCl}$. When the $\mathrm{pH}$ value is less than 6, $\mathrm{HOCl}$ approaches $100 \%$. Then combined with the disinfection mechanism of chlorine, the following conclusions can be drawn, the $\mathrm{pH}$ value has a more obvious effect on the disinfection effect of chlorine. When the $\mathrm{pH}$ value is low, the content of $\mathrm{HOCl}$ is higher, and the sterilization effect is good. When the $\mathrm{pH}$ value is low and high, the content of $\mathrm{HOCl}$ is lower and the sterilization effect is not obvious.

\subsection{Chlorine dioxide disinfection}

Chlorine dioxide is a highly oxidizing and highly effective disinfectant, and its theoretical oxidation capacity is 2.6 times that of free chlorine ${ }^{[5]}$. Chlorine dioxide has a strong bactericidal effect and can kill various microorganisms including bacterial spores ${ }^{[6]}$. There have been many studies on the mechanism of chlorine dioxide disinfection, which can basically be summarized in the following aspects: 1 . Inhibit the process of cell synthesis of protein ${ }^{[7-9]} ; 2$. It selectively interacts with certain amino acids in proteins ${ }^{[10]}$, changes the permeability of the cell membrane and causes the leakage of certain key substances in the cel[ ${ }^{[11-12]} ; 3$. Strong oxidative decomposition ability leads to breakage of amino acid chains, which makes proteins lose their function, thereby causing the death of microorganisms ${ }^{[7]}$, destruction of ATPase and lipid peroxidation, etc. ${ }^{[13]}$.

For the mechanism of chlorine dioxide,Xiaoyu Zhang et al. conducted a series of studies using Escherichia coli and obtained the following 4 pictures (2 to 5).

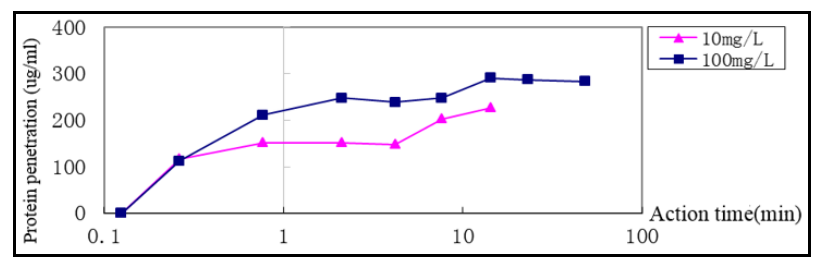

Figure 2. Protein leakage of Escherichia coli after the action of chlorine dioxide

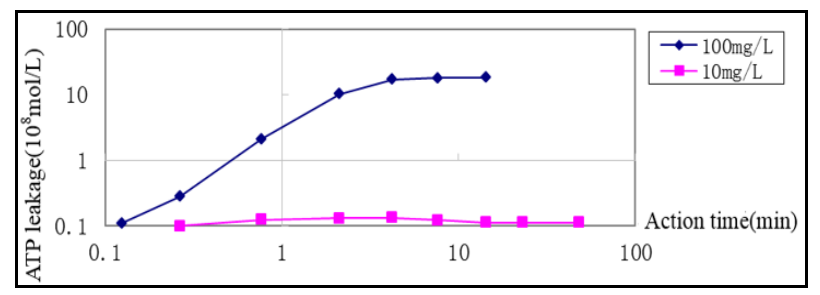

Figure 3. ATP leakage of Escherichia coli after the action of chlorine dioxide

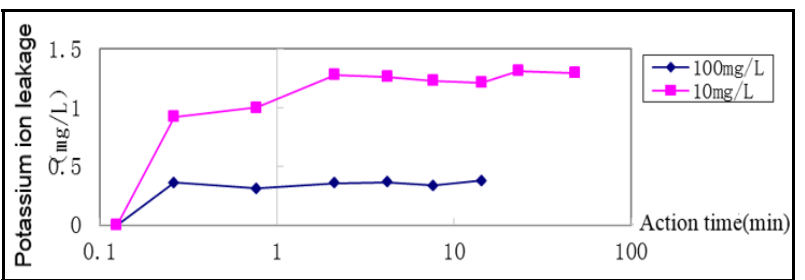

Figure 4. The leakage of potassium ions from Escherichia coli after the action of chlorine dioxide

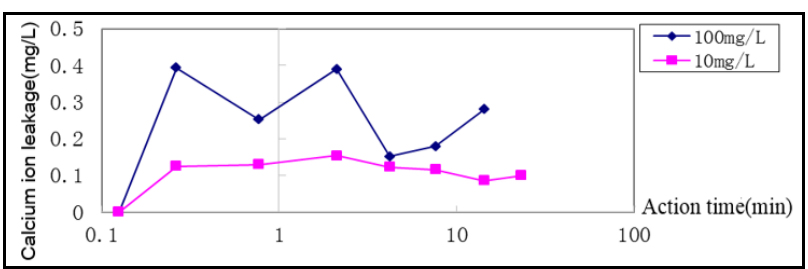

Figure 5. The leakage of calcium ions from Escherichia coli after the action of chlorine dioxide

It is not difficult to see from the figure that chlorine dioxide has the effect of changing the permeability of the cell membrane, and the higher the concentration, the more obvious the effect. Although the leakage of potassium ions in Figure 4 is obviously different from the others, this is because potassium ions are actively transported during cell transport, that is, carrier proteins are required. From this perspective, it can be inferred that chlorine dioxide has inhibitory proteins. The role of synthesis and destruction of proteins.

Chlorine dioxide is a highly effective disinfectant, which can exert a strong bactericidal effect in a small amount. Ming Zhu et al. added a certain amount of chlorine dioxide to the water sample to monitor the remaining chlorine dioxide and the number of coliforms in the water sample at $0,10,20,30,45$, and 60 minutes of the contact reaction, and obtained The following $\operatorname{data}^{[14]}$.

Table 2. When the initial dosage of chlorine dioxide is $1.60 \mathrm{mg}$, the number of remaining chlorine dioxide and coliforms changes over time

\begin{tabular}{|c|c|c|c|}
\hline $\begin{array}{c}\text { Time } \\
(\mathrm{min})\end{array}$ & $\begin{array}{c}\text { Concentration } \\
\left(\mathrm{mg} \cdot \mathrm{L}^{-1}\right)\end{array}$ & $\begin{array}{c}\text { Number of } \\
\text { coliforms }\end{array}$ & $\begin{array}{c}\text { Number of } \\
\text { repeated } \\
\text { trials }\end{array}$ \\
\hline 0 & 1.60 & 1700 & \multirow{2}{*}{} \\
\cline { 1 - 3 } & 1.02 & 1 & \multirow{2}{*}{3} \\
\hline 20 & 0.9 & 1 & \multirow{2}{*}{} \\
\hline 30 & 0.74 & 1 & \\
\hline 45 & 0.46 & 1 & \\
\hline 60 & 0.27 & 1 & \\
\hline
\end{tabular}

Table 3. When the initial dosage of chlorine dioxide is $1.40 \mathrm{mg}$, the number of remaining chlorine dioxide and coliforms changes over time

\begin{tabular}{|c|c|c|c|}
\hline $\begin{array}{c}\text { Time } \\
(\mathrm{min})\end{array}$ & $\begin{array}{c}\text { Concentration } \\
\left(\mathrm{mg} \cdot \mathrm{L}^{-1}\right)\end{array}$ & $\begin{array}{c}\text { Number of } \\
\text { coliforms }\end{array}$ & $\begin{array}{c}\text { Number of } \\
\text { repeated } \\
\text { trials }\end{array}$ \\
\hline 0 & 1.40 & 1700 & \multirow{2}{*}{} \\
\cline { 1 - 3 } & 0.67 & 2 & \multirow{2}{*}{5} \\
\cline { 1 - 3 } 20 & 0.36 & 2 & \multirow{2}{*}{} \\
\hline 30 & 0.25 & 1 & \\
\hline 45 & 0.14 & 1 & \\
\hline 60 & 0.04 & 1 & \\
\hline
\end{tabular}

It can be seen from Table 2 and Table 3 that when the dosage of chlorine dioxide reaches $1.60 \mathrm{mg} / \mathrm{L}$, the number of coliforms in the water sample has been completely inactivated after 10 minutes of reaction. The high efficiency of chlorine dioxide disinfection is evident. 


\subsection{Ozone disinfection}

Ozone, is an allotrope of oxygen,colorless, slightly odorous gas,Very strong oxidizing,under acidic conditions, its oxidation-reduction potential is $+2.07 \mathrm{~V}$, second only to fluorine at $+2.87 \mathrm{~V}$, and it is the second strong oxidant ${ }^{[15]}$. It has a strong disinfection and sterilization effect with few disinfection by-products. It is called "green disinfectant" and is widely used in the disinfection of drinking water, swimming pools, etc ${ }^{[16]-}$ [19].

The sterilization mechanism of ozone is a biochemical oxidation reaction [20]. It is generally believed that there are two ways to sterilize ozone in water: one is that ozone directly acts on the cell wall of bacteria, destroying it and causing cell death; the other is that ozone releases free radical oxygen with strong oxidizing ability when it is decomposed in water ${ }^{[21]}$. Ozone can oxidize and decompose glucose oxidase, which is necessary for oxidizing glucose in bacteria, and directly interact with bacteria and viruses to destroy their organelles and ribonucleic acid, and decompose large molecular polymers such as DNA, RNA, protein, lipids, and polysaccharides. Bacteria's material metabolism, growth and reproduction process are destroyed ${ }^{[22]}$. In addition, ozone can also penetrate the cell membrane tissue, invade the cell membrane and act on the outer membrane lipoproteins and internal lipopolysaccharides, causing the permeability of the cells to be aberrated, leading to the lysis and death of the cells. In addition, the genetic genes, parasites, parasitic virus particles, bacteriophages, mycoplasma and pyrogens (endotoxins) in the dead bacteria are dissolved and denatured to death. In terms of the principle of the effect of aseptic technology on microorganisms, ozone sterilization belongs to the bacteriolytic level, and can achieve "complete and permanent elimination of all microorganisms in the object"[20].

\subsection{Comparison of three chemical disinfection methods}

Table 4 is obtained by comparing the three disinfection methods ${ }^{[23-27]}$.

Table 4. Comparison of three chemical disinfection methods

\begin{tabular}{|c|l|l|l|l|}
\hline $\begin{array}{c}\text { Disinfecti } \\
\text { on method }\end{array}$ & Advantage & $\begin{array}{l}\text { Disadvanta } \\
\text { ge }\end{array}$ & Limitation & Economy \\
\hline \multirow{2}{*}{ chlorine } & $\begin{array}{l}\text { Low cost, } \\
\text { convenient } \\
\text { application, } \\
\text { simple } \\
\text { operation, } \\
\text { accurate } \\
\text { dosage }\end{array}$ & $\begin{array}{l}\text { High DBP } \\
\text { production, } \\
\text { strong } \\
\text { corrosivene } \\
\text { ss, long- } \\
\text { term use } \\
\text { leads to } \\
\text { bacterial } \\
\text { resistance }\end{array}$ & $\begin{array}{l}\text { The } \\
\text { sterilizatio } \\
\mathrm{n} \\
\text { efficiency } \\
\text { is greatly } \\
\text { affected by } \\
\text { the organic } \\
\text { matter and } \\
\text { pH in the } \\
\text { water }\end{array}$ & $\begin{array}{l}\text { The cost } \\
\text { per ton } \\
\text { of water } \\
\text { is } 0.003 \\
\text { yuan- } \\
0.0045 \\
\text { yuan }\end{array}$ \\
\hline
\end{tabular}

\begin{tabular}{|c|c|c|c|c|}
\hline $\begin{array}{l}\text { carbon } \\
\text { dioxide }\end{array}$ & $\begin{array}{l}\text { High } \\
\text { sterilization } \\
\text { efficiency, } \\
\text { wide } \\
\text { application } \\
\text { range of } \\
\text { pH, low } \\
\text { possibility } \\
\text { of } \\
\text { producing } \\
\text { DBP; less } \\
\text { corrosive } \\
\text { than } \\
\text { chlorine } \\
\text { and ozone }\end{array}$ & $\begin{array}{l}\text { Unstable } \\
\text { and } \\
\text { explosive. } \\
\text { When the } \\
\text { water } \\
\text { contains } \\
\text { iodide ions, } \\
\text { the amount } \\
\text { of iodate } \\
\text { produced is } \\
\text { high, } \\
\text { chlorite and } \\
\text { aluminate } \\
\text { are } \\
\text { produced, } \\
\text { and it has } \\
\text { no effect on } \\
\text { some } \\
\text { viruses. }\end{array}$ & $\begin{array}{l}\text { Suitable } \\
\text { for small } \\
\text { and } \\
\text { medium- } \\
\text { sized water } \\
\text { treatment }\end{array}$ & $\begin{array}{l}\text { Treatmen } \\
\mathrm{t} \text { cost is } \\
\text { about } \\
0.03 \\
\text { yuan per } \\
\text { ton of } \\
\text { water }\end{array}$ \\
\hline ozone & $\begin{array}{l}\text { High broad- } \\
\text { spectrum } \\
\text { antibacteria } \\
1 \text { properties, } \\
\text { killing } \\
\text { bacteria, } \\
\text { viruses and } \\
\text { spores; } \\
\text { short } \\
\text { contact } \\
\text { time, less } \\
\text { DBP } \\
\text { production; } \\
\text { can } \\
\text { increase the } \\
\text { flocculation } \\
\text { and } \\
\text { sedimentati } \\
\text { on } \\
\text { performanc } \\
\text { e of sewage }\end{array}$ & $\begin{array}{l}\text { Toxic, } \\
\text { unstable } \\
\text { and } \\
\text { corrosive if } \\
\text { inhaled }\end{array}$ & $\begin{array}{l}\text { Affected } \\
\text { by water } \\
\text { quality, it } \\
\text { is difficult } \\
\text { to realize } \\
\text { on-line } \\
\text { adjustment } \\
\text { when } \\
\text { applied to } \\
\text { occasions } \\
\text { with high } \\
\text { requiremen } \\
\text { ts on water }\end{array}$ & $\begin{array}{l}\text { The } \\
\text { initial } \\
\text { investme } \\
\text { nt cost is } \\
\text { high, and } \\
\text { the } \\
\text { operating } \\
\text { cost is } \\
\text { about } 0.1 \\
\text { yuan per } \\
\text { ton of } \\
\text { water }\end{array}$ \\
\hline
\end{tabular}

\section{Physical disinfection}

\subsection{UV disinfection}

Ultraviolet sterilization is a photochemical reaction process caused by ultraviolet photon radiation. This sterilization method can effectively remove bacterial propagules, spores, protozoa, viruses and organic pollutants in water ${ }^{[3]}$.

The mechanism of ultraviolet disinfection is a very long and complicated process. It is generally believed that microorganisms are irradiated by ultraviolet rays and absorb the energy of ultraviolet rays. The essence is the absorption of ultraviolet energy by nucleic acids. Nucleic acid is divided into RNA and DNA, which are the basic material and life foundation of all living organisms [3]. After the microbe's DNA absorbs ultraviolet light, it forms a thymine dimer and mutates, and its replication and transcription blockade are hindered, thereby hindering the synthesis of protein ribozymes in the microbe ${ }^{[28]}$; In addition, strong oxidizing free radicals are generated by photoionization energy, thereby destroying other structures of microorganisms and leading to their death ${ }^{[3]}$. 


\subsection{Micro-electrolysis disinfection}

Due to the limited level of research at present, people still do not have a unified understanding of the sterilization and disinfection mechanism of microelectrolysis. In summary, there are three points of view: First, in the electrolysis process, the chlorine produced by the electrolysis of chloride ions in the water has a bactericidal effect ${ }^{[29-30]}$; Second, the power plant's effects include electrical breakdown of the cell membrane, which can cause the bacteria to eventually hydrolyze and die by significantly changing the growth environment of the bacteria, or through the electron transfer between the bacterial cell and the click, causing the bacterial cell's respiratory system to become imbalanced and lead to the death of the bacteria; Third, some high-activity, low-life free radicals generated during the electrolysis process, such as oxygen anion radicals, hydroxyl radicals, hypochlorous acid anion radicals and chlorine dioxide anion radicals, are very strong. Bactericidal effect ${ }^{[31-32]}$.

\subsection{Ultrasonic disinfection}

The so-called ultrasonic disinfection is a disinfection method that uses sound waves with a frequency of more than $20 \mathrm{kHz}$ to kill microorganisms in the water. The principle is that by applying an ultrasonic field in the water, the liquid produces clusters of bubbles-"cavitation bubbles". When these bubbles are subjected to ultrasound, they will undergo bubble growth, contraction, re-growth, and re-shrinkage processes, and after repeated periodic oscillations, they will eventually burst at a high speed. In the process of its periodic oscillation or collapse, it will produce short-term local high temperature (about 5000K) and high pressure (about $100 \mathrm{MPa}$ ), heating and cooling rates greater than $1000 \mathrm{~K} / \mathrm{s}$, and generate a strong electric field, which triggers mechanics, heat, chemistry and biology Academic effect $^{[33]}$.

\subsection{Comparison of three physical disinfection methods}

Table 5 is obtained by comparing the three disinfection methods $^{[34-38]}$.

Table 5. Comparison of three physical disinfection methods

\begin{tabular}{|c|c|c|c|c|}
\hline $\begin{array}{l}\text { Disinfection } \\
\text { method }\end{array}$ & Advantage & $\begin{array}{l}\text { Disadvant } \\
\text { age }\end{array}$ & Limitation & Economy \\
\hline $\begin{array}{c}\text { Ultraviolet } \\
\text { rays }\end{array}$ & $\begin{array}{c}\text { Safe, fast, } \\
\text { no water } \\
\text { pollution, } \\
\text { fast } \\
\text { disinfectio } \\
\text { n speed, } \\
\text { easy } \\
\text { operation, } \\
\text { no by- } \\
\text { products }\end{array}$ & $\begin{array}{c}\text { Without } \\
\text { continuous } \\
\text { sterilizatio } \\
\mathrm{n} \text { ability, } \\
\text { microbes } \\
\text { will } \\
\text { undergo } \\
\text { light } \\
\text { resurrectio } \\
\text { n } \\
\text { phenomen } \\
\text { on }\end{array}$ & $\begin{array}{c}\text { Affected } \\
\text { greatly by } \\
\text { suspended } \\
\text { solids in } \\
\text { water, } \\
\text { chroma, } \\
\text { hardness, } \\
\text { and iron } \\
\text { content }\end{array}$ & $\begin{array}{c}\text { Low } \\
\text { investme } \\
\text { nt and } \\
\text { operating } \\
\text { costs }\end{array}$ \\
\hline
\end{tabular}

\begin{tabular}{|c|c|c|c|c|}
\hline $\begin{array}{c}\text { Microelectro } \\
\text { lysis }\end{array}$ & $\begin{array}{c}\text { Simple } \\
\text { operation } \\
\text { and simple } \\
\text { equipment }\end{array}$ & $\begin{array}{c}\text { Large } \\
\text { energy } \\
\text { consumpti } \\
\text { on, } \\
\text { uncertain } \\
\text { products }\end{array}$ & $\begin{array}{l}\text { Affected by } \\
\text { the } \\
\text { concentrati } \\
\text { on of } \\
\text { chloride } \\
\text { ions in the } \\
\text { water }\end{array}$ & $\begin{array}{l}\text { Low } \\
\text { cost, but } \\
\text { higher } \\
\text { operating } \\
\text { cost }\end{array}$ \\
\hline Ultrasound & $\begin{array}{c}\text { Simple } \\
\text { method, } \\
\text { fast speed, } \\
\text { high } \\
\text { efficiency, } \\
\text { easy to } \\
\text { adjust }\end{array}$ & $\begin{array}{l}\text { The actual } \\
\text { operation } \\
\text { is not ideal } \\
\text { and the } \\
\text { energy } \\
\text { consumpti } \\
\text { on is large }\end{array}$ & $\begin{array}{l}\text { Limited to } \\
\text { the area } \\
\text { close to the } \\
\text { ultrasonic } \\
\text { emission }\end{array}$ & $\begin{array}{c}\text { High } \\
\text { operating } \\
\text { cost }\end{array}$ \\
\hline
\end{tabular}

\section{Combined disinfection method}

Judging from the current operation of water plants, it is difficult to control the total number of coliforms in the reclaimed water within $3 / \mathrm{L}$ with a single disinfection method, and various chemical disinfection methods will produce certain by-products, while physical methods have no by-products. The production of products, but the cost is high and there is no continuous disinfection ability, then the combination of two or more disinfection processes can theoretically not only improve the effect of killing microorganisms, but also reduce the generation of bacterial resistance and reduce the concentration of disinfection. Shorten the disinfection time, while ensuring economy ${ }^{[1]}$. The four typical combined disinfection processes listed in this article are: ozone and ultrasonic combined disinfection, ozone and chlorine combined disinfection, ozone combined with ultraviolet disinfection, and ultraviolet combined with chlorine disinfection.

\subsection{Ozone and ultrasonic disinfection}

The cavitation produced by ultrasonic waves at a certain frequency can break microbial cells and kill some microbes. The combined use of ultrasonic or hydrodynamic cavitation and ozone can reduce ozone consumption, thereby reducing the amount of ozone disinfection by-products, while reducing energy consumption. The combination of the two has a better disinfection effect than using ozone and ultrasonic cavitation alone $\mathrm{e}^{[39-40]}$.

\subsection{Ozone and chlorine combined disinfection}

Adding a small amount of chlorine or ammonium chloride after ozone disinfection can stabilize the water quality of the pipe network. Ozone oxidation can lead to changes in the types of typical by-products and changes in the amount of follow-up chlorination process. At the same time, ozone oxidation can effectively reduce the genotoxicity of the effluent. Subsequent chlorination and continuous disinfection have less impact on the genotoxicity ${ }^{[41]}$. 


\subsection{Ozone and ultraviolet combined disinfection}

Ozone is consumed in sewage disinfection. Catalytic oxidation can be used to increase the oxidation efficiency of ozone to reduce the amount of ozone used. Catalytic oxidation belongs to the category of advanced oxidation, and the oxidation ability of ozone is improved under the action of a catalyst. Ozone/ultraviolet, ozone/hydrogen peroxide combined process belongs to ozone catalytic oxidation process. In addition, certain metals and metal oxides also have the effect of catalyzing ozone ${ }^{[42]}$. BSOh et al. found that the sterilization effect of using ozone-ultraviolet combined method to disinfect reused sewage is better than that of using ozone or ultraviolet alone ${ }^{[43]}$. This is mainly because ultraviolet catalysis causes ozone to produce a large amount of $\cdot \mathrm{OH}$ in the water, which enhances its oxidation. The ability and sterilization effect are improved.

\subsection{UV and chlorine combined disinfection}

Combination of ultraviolet and chlorine disinfection is an efficient, economical, thorough and long-lasting disinfection method. On the one hand, it can make up for the disadvantage that a single chlorine disinfection cannot kill cryptosporidium, flagellum and other protozoa, and it can make up for the shortcomings of single ultraviolet disinfection that has no continuous disinfection effect, and can well prevent the occurrence of bacterial photoresurrection; On the one hand, it can also reduce the amount of chlorine used, reduce the generation of disinfection by-products in the water, and reduce the biological toxicity of the water ${ }^{[44]}$. XiuJuan Wang et al. found through experiments that a small dose of ultraviolet radiation supplemented with a small dose of chlorine for disinfection treatment can play the role of a large dose of ultraviolet alone or a large dose of chlorine alone ${ }^{[45]}$.

\section{Prospects for the research direction of reclaimed water disinfection technology}

First, for mature disinfection methods, it is necessary to research and develop more efficient and energy-saving equipment to reduce disinfection costs; second, to research and develop more efficient and environmentally friendly disinfectants to replace disinfectants that are prone to secondary pollution; third, Continue to strengthen the research on the disinfection mechanism, and find effective methods to improve the disinfection effect; fourth, strengthen the kinetic research to improve the ability to predict and control the disinfection process $^{[1]}$.

\section{Conclusion}

In the near future, with the development of science and technology, the reclaimed water treatment process will be more diversified, the investment will be lower, and the treatment process will be more energy-saving and environmentally friendly.

\section{References}

1. Zhang P.F,Li X.Y, Song B, et al. (2011)Discussion on Reclaimed Water Disinfection Technology [J]. Value Engineering,30(3):320-320.

2.Atkinson R, Baulch D.L, Cox R.A.(2007) Evaluated kinetic and photochemical data for atmospheric chemistry: Volume III-gas phase reactions of inorganic halogens $[\mathrm{J}]$. Atmos. Chem. Phys, 2007(7):981-1191.

3.Guo B.D,Xing Y,Zhang X. (2006)Application of Disinfection Technology in Reuse of Reclaimed Water $[\mathrm{J}]$. Environmental Sanitation Engineering, 14(4):63-64.

4.Yan X.S,Fan J.C. (2009)Drainage Works [M].China Architecture.

5.Yan Q.W. (2002)Chlorine Dioxide Used in Water Treatment Technology [J].Guizhou Chemical Industry, 027(1):33-35.

6.Zhang X.Y,Wu Q.P,Zhang J.M, et al. (2007)Study on the Mechanism of Chlorine Dioxide on Escherichia coli [J].Chinese Journal of Disinfection, 24(1):16-20.

7.Olivieri VP, Sneal MC, Kruse CW, et al.(1986) Stability and effectiveness of chlorie disinfectants in water distribution system[J]. Environ Health Perspect, 69:15.

8.Charles I Noss, Fred S. Hauchman and Vincent P. Olivieri.(1986) Chlorine dioxide reactivity with proteins[J]. Water Res, 20(3):351.

9.Benarde MA, Snow WB, Olivieri VP, et al. (1967)Kinetics and mechanism of bacteria disinfection by chlorine dioxide[J]. Applied Micro, 15(2):257.

10.Tan H.K.(1987) Reaction of chlorine dioxide with amino acids and peptides kinetics and mutagenicity studies[j]. Mutat Res, 188(4):259.

11.Chen C.T,Li D.L,Liu X.Z, et al.(2002) Experimental Observation on the Mechanism of Chlorine Dioxide Killing Bacteria [J]. Chinese Journal of Disinfection, 19(3):137.

12.Liu X.L,Tu Y,Wang Q.M. (1994)Effect of Chlorine Dioxide on the Ultrastructure and Barrier Function of Escherichia coli [J]. Chinese Journal of Public Health,13(3):159-161.

13. Liu X.L,Tu Y,Wang Q.M.(1996) Effect of Chlorine Dioxide on E. coli ATPase and Lipids [J]. Chinese Journal of Disinfection, 13(2):73-75.

14.Zhu M,Ma L.S,Wang S.W, et al. (2010)Study on the Kinetics of Chlorine Dioxide Disinfecting Water [J]. Hebei Chemical Industry, 33(10):34-36.

15.Yang J.C,Zeng K.M,Liang H, et al. (2004) Application of Ozone Method in Urban Sewage Disinfection $[\mathrm{J}]$. Environmental Science and Technology, 27(1):64-65. 
16.Hulya Olmez, Ursula Kretzschmar.(2009) Potential alternative disinfection methods for organic freshcut industry for minimizing water consumption and environmental impact[J]. LWT-Food Science and Technology, 42(3):686-693.

17.Jiang S.K, Xiao K.D. (2008)Application of OzoneBiological Activated Carbon Technology in Drinking Water Treatment [J]. Shanxi Architecture, 34(23):16-17.

18.Zhu H.W. (2008)Application of Ozone Disinfection and Chlorine Disinfection in Swimming Pool Circulating Water $[\mathrm{J}]$. Southwest Water and Wastewater,30(4):28-29.

19.Rodriguez A, Rosal R, Perdigon-Melon JA, et al.(2008) Ozone-based technologies in water and wastewater treatment: the handbook of environmental chemistry, Vol.5[M]. Berlin Heidelberg; Springer-Verlag.

20.Wang X.Y, Chen H.B, Ruan J.L.(2010) Research and Aapplication of Ozone Disinfection of Sewage and Reclaimed Water [J]. Technology of Water Treatment,36(4):19-23.

21.Xia Z.Q, Yang J, Ding C.W.(2006) Introduction to Ozone Disinfection [J]. Journal of Chemical Education, 10:7-9.

22.Hou W.G. (2000)Ozone Technology Application Research [J]. Pharmaceutical Engineering Design, 21(6):255-257.

23.Fang M. (2002)Study on the Stability of Ozone Water [J]. Food Research,23(9):39-43.

24.Ernest R, Blatchley, Bruce A, et al. (1997)Effects of disinfectants on wastewater effluent toxicity[J]. Water Research, 31(7):1581-1588.

25.He T, E X.L, Wang H.W,et al. (2008)Study on the Generation Regularity and Influencing Factors of the By-products of Chlorine Dioxide Water Disinfection [J]. Journal of Environmental and Health ,25(2):101-103.

26.Zhang L.C. (2001)Comparison of Ultraviolet Disinfection and Four Chemical Disinfection Methods $[\mathrm{J}]$. Liaoning Chemical Industry, 30(12):533-536.

27.Wang R.S. (2003)Chlorine Disinfection and Other Chlorine Control Technology in the Tail Water of Municipal Sewage Plants [J]. Guangzhou Environmental Sciences, 18(4):8-11.

28.Wang Y.Y. (2011)Selection of Disinfection Process for Sewage and Reclaimed Water [J]. Information of China Construction.Water-Industry Market,5:50-52.

29.Colgan S, Gehr R. (2001)Disinfection[J]. Water Environ Technol, 13:29-33.

30.Stampi S, De Luca G, Zanetti F.(2001) Evaluation of the efficiency of peracetic acid in the disinfection of sewage effluents[J]. J. Appl. Microbiol, 91:833-838.

31.Diao H.F, Li X.Y, Gu J.D, et al. (2004)Electron microscop ic investigation of the bactericidal action of electrochemical disinfection in comparison with chlorination. Ozonation and Fenton reaction[J]. Process Biochem, 39:1421-1426.

32.Kevin P. Drees, Morteza Abbaszadegan, Raina M. Maier. (2003) Comparative electrochemical inactivation of bacteria and bacteriophage $[\mathrm{J}]$. Water Res, 37:2291-2300.

33.Li C.X, Wang J.G, Wang Z.H,et al.(2001) Application and Research Progress of Ultrasonic Technology in Wastewater Treatment [J]. Techniques and Equipment for Environmental Pollution Control, 2(2):64-49.

34.Lou C.G, Xia D.S, Lin C.Y,et al. (2009)Research on Electroless Ultraviolet Light Disinfection in Reclaimed Water [J]. Southwest Water and Wastewater, 31(5):22-24.

35.Zhang P.F, Yang Y.J, Zhang W.C, et al.(2010) Study on the Effect of GAC Enhanced Sand Filtration on Ultraviolet Disinfection of Reclaimed Water [J]. Water and Wastewater Engineering,37(2):43-46.

36.Zhao S.G, Zhang Z.Y, Guo X.W. (2009)Application of Micro-current Point Solution Disinfection Technology in Seawater Micro-generation System [J]. Technology of Water Treatment, 35(3):66-68.

37.Fu J.X, Zhao Y.H, Fan M.J,et al.(2001) Study on the Influence Factors of Micro-electrolysis Disinfection Process [J]. China Water and Wastewater,17(11):5-7.

38.Wang W.Z. (2003)Disinfect Sewage With Ultraviolet Light $[\mathrm{J}]$. Energy Conservation and Environmental Protection,(5):44-45.

39.K K Jyoti, A B Pandit. (2004)Ozone and cavitation for water disinfection[J]. Biochemical Engineering Journal, (18):9-19.

40.Rashmi Chand, David H Bremner, Kyu C Namkung, et al. (2007)Water disinfection using the novel approach of ozone and a liquid whistle reactor[J]. Biochemical Engineering Journal, (35):357-364.

41.Miao T.T. (2008)The Influence of Chlorine and Ozone Disinfection Technology on the Quality of Urban Sewage [D]. Beijing: Beijing University of Technology.

42.Han B.J. (2007)Research on the Decontamination Characteristics of Ozone Catalytic Oxidation and Its Production Application [D]. Harbin : Harbin Institute of Technology.

43.B S Oh, S J Park, Y J Jung, et al. (2008)Disinfection and oxidation of sewage effluent water using ozone and UV technologies[J]. Water Science \& Technology, 55(1):299-306.

44.Yang C, Wang X.Y, Wang D, et al. (2011)Comparative Analysis of UV-chlorine Combined Disinfection and Single Chlorine Disinfection of Reclaimed Water [J]. Water Technology, 5(1):19-22.

45.Wang X.J, Hu X.X, Hu C, et al.(2011) Sequential use of ultraviolet light and chlorine for reclaimed water disinfection[J]. Journal of Environmental Sciences, 23(10):1605-1610. 